\title{
STUDI REALITAS PENGUASAAN TEORI DAN PRAKTEK TAJWID DI KALANGAN MAHASISWA PRODI IPAI FPIPS UPI ANGKATAN 2012-2014
}

\author{
Risa Haelani, * \\ Saepul Anwar, Udin Supriadi \\ Program Studi Ilmu Pendidikan Agama Islam, \\ Fakultas Pendidikan Ilmu Pengetahuan Sosial, Universitas Pendidikan Indonesia \\ *Email : risahaelani04@gmail.com
}

\begin{abstract}
ABSTRAK
Penelitian ini dilatar belakangi oleh kenyataan bahwa guru yang professional khususnya guru PAI sangatlah penting. Bagi guru PAI, menguasai ilmu tajwīd adalah keharusan. Prodi Ilmu Pendidikan Agama Islam (IPAI) UPI Bandung adalah prodi yang mencetak calon-calon guru PAI. Akan tetapi di IPAI itu sendiri tidak ada mata kuliah yang secara khusus mengkaji tentang ilmu tajwīd, padahal penguasaan ilmu tajwīd merupakan salah satu indikator untuk mencetak guru PAI yang professional.

Penelitian ini bertujuan untuk memperoleh gambaran atau realitas penguasaan teori dan praktek tajwīd di kalangan mahasiaswa/mahasiswi prodi IPAI FPIPS UPI angkatan 20122014 serta hal yang mempengaruhi realitas tersebut. Penelitian ini menggunakan metode penelitian deskriptif dengan pendekatan kuantitatif. Metode ini digunakan untuk mengungkap realitas penguasaan teori dan praktek tajwīd di kalangan mahasiswa/mahasiswi prodi IPAI FPIPS UPI. Dalam pengumpulan data peneliti menggunakan dua metode yaitu angket dan tes. Dalam analisis data, peneliti menggunakan statistik deskriptif dan statistik inferensia.

Berdasarkan hasil penelitian, diperoleh gambaran atau realitas bahwa penguasaan teori dan praktek tajwīd di kalangan mahasiswa/mahasiswi prodi IPAI FPIPS UPI ini belum begitu baik. Hal ini ditandai dengan adanya beberapa variabel teori tajwid yang belum mereka ketahui seperti sifat khuruf, bacaan musykilat dan tanda wakaf. Selain itu, dalam praktek tajwid, peneliti menggunakan alat ukur dengan tes membaca al-Qur'an dan hasilnya mereka belum benar-benar mencapai pada tingkat fasih atau pun tahsīn. Faktor yang mempengaruhi hal tersebut bisa dikatakan karena latar belakang mahasiswa/mahasiswi prodi IPAI FPIPS UPI ini mayoritas tidak memiliki latar belakang keagamaan (Pesantren).
\end{abstract}

Kata kunci : Studi Realitas, Profesional, Penguasaan, Tajwìd, Praktek 


\section{PENDAHULUAN}

Semua Guru, termasuk Guru PAI, dituntut harus memiliki kualifikasi akademik dan kompetensi sebagai agen pembelajaran, sehat jasmani dan rohani, serta memiliki kemampuan untuk mewujudkan tujuan pendidikan nasional yang tercantum di dalam Bab VI Standar Pendidikan dan tenaga kependidikan pasal 28 ayat (1). Selanjutnya pada ayat ke (2) Kualifikasi akademik sebagaimana di maksud padaayat (1) adalah tingkat pendidikan minimal yang harus dipenuhi oleh seorang pendidik yang di buktikan dengan ijazah dan/atau sertifikat keahlian yang relevan sesuai ketentuan perundangundangan yang berlaku. Yang paling terpenting pada ayat ke (3) bahwa seorang pendidik harus memiliki kompetensi sebagai agen pembelajaran pada jenjang pendidikan dasar dan menengah serta pendidikan anak usia dini meliputi

(a)Kompetensi pedagogik;

(b)Kompetensi Kepribadian;

(c)Kompetensi Profesional;

(d)Kompetensi Sosial.

Sejalan dengan itu seorang pendidik atau guru harus memiliki kompetensi professional, Menurut Saudagar,(2009:48) di-dalam bukunya yang berjudul pengembangan profrsionalitas guru, guru profesional adalah guru yang memiliki kompetensi yang dipersyaratkan untuk melakukan tugas pendidikan dan pengajaran. Kompetensi tersebut meliputi pengetahuan, sikap, dan keterampilan profesional, baik bersifat pribadi, sosial, maupun akademis. Kompetensi profesional merupakan salah satu kemampuan dasar yang harus dimiliki oleh seorang guru. Dalam Peraturan Pemerintah Nomor 19 Tahun 2005, pada pasal 28 ayat 3 yang dimaksud dengan kompetensi profesional adalah kemampuan penguasaan materi pembelajaran secara luas dan mendalam yang memungkinkannya membimbing peserta didik memenuhi standar kompetensi yang di tetapkan dalam Standar Pendidikan Nasional. Sedangkan menurut Mukhlas Samani (2008;6) yang dimaksud dengan kompetensi profesional adalah kemampuan menguasai pengetahuan bidang ilmu, teknologi dan atau seni yang diampunya meliputi penguasaan :

a. Materi pelajaran secara luas dan mendalam sesuai dengan standar isi program satuan pendidikan, mata pelajaran, dan atau kelompok mata pelajaran yang diampunya.

b. Konsep konsep dan metode disiplin keilmuan, teknologi, dan atau seni yang relevan yang secara konseptual menaungi atau koheren dengan program satuan pendidikan, mata pelajaran, dan atau kelompok mata pelajaran yang akan di ampunya.

Bagi guru yang merupakan tenaga profesional dibidang kependidikan dalam kaitannya dengan accountabillity, bukan berarti tugasnya menjadi ringan, tetapi justru lebih berat dalam rangka memberikan pelayanan kepada masyarakat. Oleh karena itu, guru dituntut memiliki kualifikasi kemampuan yang lebih memadai. Secara garis besar ada tiga tingkatan kualifikasi profesional guru sebagai tenaga kependidikan. Yang pertama adalah tingkatan capability personal, maksudnya guru diharapkan memiliki pengetahuan kecakapan dan keterampilam serta sikap yang lebih mantap dan memadai sehingga mampu mengelola proses belajar mengajar secara efektif. Tingkatan kedua adalah guru sebagai inovator, yakni sebagai tenaga kependidikan yang memiliki komitmen terhadap upaya perubahan dan reformasi. Para guru diharapkan memiliki pengetahuan, kecakapan dan keterampilan serta sikap yang tepat terhadap pembaharuan dan sekaligus merupakan penyebar ide pembaharuan yang efektif. Tingkatan ketiga adalah guru sebagai visioner. Selain menghayati kualifikasi yang pertama dan kedua guru harus 
memiliki visi keguruan yang mantap dan luas perspektifnya. Guru harus mampu dan mau melihat jauh ke depan dalam menjawab tantangan-tantangan yang dihadapi oleh sektor pendidikan sebagai suatu sistem.

\section{METODE}

Penelitian yang dilakukan merupakan penelitian Kuantitatif deskriptif dan statistika inferensia. Umumnya peneliti menggunakan instumen (alat ukur) untuk mengumpulkan data. Menurut (Sugiyono, 2011) dalam penelitian kuantitatif dapat berupa tes, pedoman wawancara, pedoman observasi dan kuisieoner (angket). Adapun dalam penelitian ini, peneliti akan menggunakan kuisioner dalam bentuk angket dan tes dalam penelitiannya. Menurut Riduwan (2012, hlm. 71) Angket adalah daftar pertanyaan yang diberikan kepada orang lain bersedia memberikan respons (responden) sesuai dengan permintaan pengguna. Tujuan penyebaran angket ialah mencari informasi yang lengkap mengenai suatu masalah dan responden tanpa merasa khawatir bila responden memberikan jawaban yang tidak sesuai dengan kenyataan dalam pengisian daftar pertanyaan. Di samping itu, responden mengetahui informasi tertentu yang diminta.

Partisipan adalah orang yang berpartisipasi di dalam penelitian.Yang berpartisipasi di dalam penelitian ini adalah mahasiswa/mahasiswi Prodi IPAI FPIPS UPI Angkatan 2012-2014.

Dalam penggunaannya, angket untuk penelitian ini harus mampu memudahkan peneliti dalam memperoleh data yang dibutuhkan. Untuk itu peneliti juga harus senantiasa memperhatikan teknik perumusan angketnya. Angket dalam penelitian ini harus dirumuskan dengan cermat agar mampu mengungkap keadaan nyata dilapangan atau realitas dan juga mengungkap bagaimana harapan dan kenyataan seputar penguasaain ilmu tajwid.

Sugiyono (2011, hlm. 207) dalam penelitian kuantitatif, analisis data merupakan kegiatan setelah data dari seluruh responden atau sumber data lain terkumpul. Teknik analisis data dalam penelitian kuantitatif menggunakan statistik. Terdapat beberapa dua macam statistik yang digunakan untuk analisi data dalam penelitian,yaitu : statistik deskriptif, dan statistik inferensial.

Statistik deskriptif adalah statistik yang digunakan untuk menganalisis data dengan cara mendeskripsikan atau menggambarkan data yang telah terkumpul sebagaimana adanya tanpa bermaksud membuat kesimpulan yang berlaku untuk umum atau generalisasi.

\section{HASIL PENELITIAN DAN PEMBAHASAN}

Berdasarkan uraian metode penelitian tersebut diperoleh data berdasarkan hasil angket dan tes penguasaan teori dan praktek tajwīd di kalangan mahasiswa Prodi IPAI FPIPS UPI.

\section{A. Hasil Penelitian}

\section{Penguasaan teori tajwid a. Angkatan 2012}

Diketahui bahwa dari hasil sebaran angket berdasrkan responden diketahui 9 (21\%) responden angkatan 2012 yang masuk ke dalam kategori baik, 19 (45\%) berada dalam kategori cukup, 13 (31\%) berada dalam kategori kurang baik dan sisanya $1(3 \%)$ dalam kategori tidak baik. Hasil diatas digambarkan dalam diagram pie sebagai berikut.

Selain itu, diketahui bahwa sebanyak dari hasil sebaran angket berdasarkan penguasaan teori tajwīd diketahui bahwa 
sebagian besar responden angkatan 2012 dari 12 sub kategori penguasaan, menguasai sebagian besar menguasai hukum Idgām sagir, hukum gunnaћ, hukum mad far'i, hukum mim mati, hukum Qalqalaћ, hukum Tafkhìm dan Tarqīq, hukum bacaan musykilat. Sedangkan untuk kategori sifat huruf dan tanda waqaf, responden angkatan 2012 hampir sebagian kecil menguasai kategori tersebut. dan yang terakhir hampir seluruhnya menguasai mad tobi'i dan hukum alif lām.

\section{b. Angkatan 2013}

iketahui 13 (25\%) responden angkatan 2013 yang masuk ke dalam kategori baik, 23 (45\%) berada dalam kategori cukup, 12 (26\%) berada dalam kategori kurang baik dan sisanya $3(6 \%)$ dalam kategori tidak baik.

Diketahui pula bahwa sebanyak dari hasil sebaran angket berdasarkan penguasaan teori tajwīd diketahui bahwa sebagian besar responden angkatan 2013 dari 12 sub kategori penguasaan, menguasai hampir setengahnya sifat huruf. Sebagian besar menguasai hukum Idgām sagir, hukum gunnah, hukum mad far'i, hukum mim mati, hukum Qalqala, hukum Tafkhìm dan Tarqīq, hukum bacaan musykīlat dan tanda waqaf. Dan yang terakhir hampir seluruhnya menguasai mad tobi'i dan hukum alif làm.

\section{c. Angkatan 2014}

Diketahui bahwa dari hasil sebaran angket berdasarkan responden diketahui 9 (18\%) responden angkatan 2014 yang masuk ke dalam kategori baik, 19 (35\%) berada dalam kategori cukup, 17 (31\%) berada dalam kategori kurang baik dan sisanya $9(16 \%)$ dalam kategori tidak baik.

Diketahui pula bahwa sebanyak dari hasil sebaran angket berdasarkan penguasaan teori tajwīd diketahui bahwa sebagian besar responden angkatan 2012 dari 12 sub kategori penguasaan, menguasai sebagian kecil menguasai sifat huruf, sebagian besar hukum nūn mati dan tanwīn, hukum Idgām sagir, hukum gunnaћ, hukum mad Tabi'i, hukum mad far'i, hukum mìm mati, hukum Qalqala, hukum alif Lām hukum Tafkhìm dan Tarqīq, hukum bacaan musykīlat. Sedangkan untuk kategori sifat huruf dan tanda waqaf. Terakhir hampir setengahnya hukum bacaan musykīlat serta lebih dari setengahnya menguasai tanda waqaf.

\section{Penguasaan praktek Tajwid}

\section{a. Angkatan 2012}

Diketahui bahwa hasil dari penguasaan praktek tajwīd tersebut di angkatan 2012 ari 42 responden, sebanyak $38(90 \%)$ responden yang memiliki jumlah skor 4 yang dikategorikan hampir seluruhnya berada pada skor tersebut dan berada pada tingkatan terampil (TT). Selanjutnya hanya $4(10 \%)$ responden saja yang memiliki jumlah skor 5 dan berada pada tingkatan mahir (TM) dan itu artinya yang masuk ke Dalam kategoi sedikit sekali yang memiliki skor tersebut. Hasil di atas digambarkan Dalam diagram pie sebagai berikut.

\section{b. Angkatan 2013}

Diketahui bahwa hasil dari penguasaan praktek tajwīd tersebut di angkatan 2013 dari 51 responden, sebanyak 43 (84\%) responden yang memiliki jumlah skor 4 yang dikategorikan hampir seluruhnya berada pada skor tersebut dan berada pada tingkatan terampil (TT). Selanjutnya hanya $8(16 \%)$ responden saja yang memiliki jumlah skor 5 dan berada pada tingkatan mahir (TM) dan itu artinya yang masuk ke Dalam kategoi sedikit sekali yang memiliki skor tersebut. Hasil di atas digambarkan dalam diagram pie sebagai berikut:

\section{c. Angkatan 2014}

Diketahui bahwa hasil dari penguasaan praktek tajwīd tersebut di angkatan 2014 
dari 56 responden, sebanyak $49(87,5 \%)$ responden yang memiliki jumlah skor 4 yang dikategorikan hampir seluruhnya berada pada skor tersebut dan berada pada tingkatan terampil (TT). Selanjutnya hanya $7(12,5 \%)$ responden saja yang memiliki jumlah skor 5 dan berada pada tingkatan mahir (TM) dan itu artinya yang masuk ke dalam kategoi sedikit sekali yang memiliki skor tersebut.

\section{Perbandingan tiap angkatan}

Diketahui bahwa Frekuensi Angkatan 2012 berjumlah 42, lalu 2013 berjumlah 51, dan terakhir 2014 berjumlah 55. Nilai rata-rata yang paling besar diperoleh oleh angkatan 2012 dengan jumlah sebesar 4,31. Secara umum, rata-rata tiap angkatan berbeda. Kesimpulan yang dapat diambil adalah bahwa data tersebut atau setiap angkatan memiliki perbedaan rata-rata.

Diketahui bahwa Frekuensi Angkatan 2012 berjumlah 42, lalu 2013 berjumlah 51, dan terakhir 2014 berjumlah 55. Nilai rata-rata yang diperoleh oleh angkatan masing masing angkatan tidak jauh berbeda dalam kategori teori tajwīd. Secara umum, dalam kategori penguasaan praktek tajwīd tidak berbeda.

\section{Pengaruh latar belakang pendidikan terhadap penguasaan teori dan praktek tajwīd}

Uji hipotesis pada penelitian ini menggunakan uji $\mathrm{t}$ yang dimaksudkan untuk mengetahui dan memastikan hasil yang diperoleh dari analisis regresi linier apakah variabel independent berpengaruh atau tidak terhadap variabel dependent. Dalam penelitian ini diketahui:

Ho : Tidak Adanya pengaruh antara lataer belakang pendidikan terhadap penguasaan teori tajwīd.

$\mathrm{Ha}$ : Adanya pengaruh antara latar belakang pendidikan terhadap penguasaan teori tajwīd.
Dengan menggunakan SPSS V.21 diperoleh hasil :

Maka dengan pengambilan keputusan berdasarkan probabilitas jika probabilitas Ho $>0,05$ maka Ho diterima, sedangkan apabila <0,05 maka Ha diterima dan Ho ditolak. Pada hasil yang diperoleh Sig. berada $>0,05$ dengan jumlah signifikansi sebesar 0,085. Artinya tidak adanya pengaruh latar belakang pendidikan terhadap penguasaan teori tajwīd.

Maka dengan pengambilan keputusan berdasarkan probabilitas jika probabilitas Ho $>0,05$ maka Ho diterima, sedangkan apabila $<0,05$ maka Ha diterima dan Ho ditolak. Pada hasil yang diperoleh Sig. berada $>0,05$ sebesar 0,077Artinya tida adanya pengaruh latar belakang pendiikan terhadap penguasaan praktek tajwīd.

\section{B. Pembahasan}

Setelah hasil penelitian berhasil didapatkan melalui analisis data.Setelah pengolahan data, maka di dapat hasil seperti yang ada di atas.Hasil tersebut telah menjawab rumusan maslah yang ada dalam penelitian ini.Akan tetapi, tentu saja hasil tersebut hanyalah berupa tingkat kemampuan yang menūnjukkan penguasaan teori dan praktek tajwīd di kalangan mahasiswa/mahasiswi PRODI IPAI. Tingkatan tersebut memerlukan pemaknaan yang lebih dalam, maka pada pembahasan berikutnya, akan dibahas satu per satu per variabel hasil penelitian ini, mengenai penguasaan teori dan praktek tajwìd, perbandingan tiap angkatan dan pengaruh latar belakang pendidikan terhadap penguasaan teori dan praktek tajwīd.

\section{Penguasaan teori tajwīd}

Proses pelaksanaan penelitian yang dilakukan di Prodi IPAI angkatan 20122014 ini dengam sampel 148 responden. Untuk angkatan 2012 dengan jumlah responden 42 responden ini berjalan 
dengan cukup. Berdasarkan hasil penelitian, hasil rata-rata pemahaman atau penguasaan teori tajwīd tersebut, angkatan 2012 sebanyak 9 responden dengan jumlah prosentase sebesar 21\% mendapatkan kategori baik, 19 responden dengan jumlah prosentase $45 \%$ mendapatkan kategori cukup, 13 responden dengan jumlah prosentase $31 \%$ mendapatkan kategori kurang baik dan yang terakhir hanya 1 responden saja dengan jumlah prosentase 3\% mendapatkan kategori tidak baik.

Untuk angkatan 2013 dengan jumlah 51 responden pun berjalan dengan cukup baik. Berdasarkan hasil penelitian, hasil rata-rata pemahaman atau penguasaan teori tajwīd tersebut, angkatan 2013 sebanyak 13 responden dengan jumlah prosentase sebesar $25 \%$ mendapatkan kategori baik, 23 responden dengan jumlah prosentase $45 \%$ mendapatkan kategori cukup, 12 responden dengan jumlah prosentase sebesar $26 \%$ mendapatkan kategori kurang baik dan terakhir 3 responden dengan prosentase sebesar $6 \%$ berada pada kategori tidak baik.

Selanjutnya untuk angkatan 2014, dengan jumlah 56 responden juga berjalan dengan cukup baik. Berdasarkan hasil penelitian, hasil rata rata pemahaman atau penguasaan teori tajwīd tersebut, sebanyak 10 responden dengan jumlah persentase $18 \%$ mendapatkan kategori baik, 19 responden dengan jumlah persentase $35 \%$ mendapatkan kategori cukup. Selanjutnya 17 responden dengan jumlah persentase $31 \%$ mendapatkan kategori kurang baik dan sisanya sebanyak 9 responden dengan jumlah persentase $16 \%$ mendapatkan kategori tidak baik.

Pada ranah penguasaan teori tajwīd, rata-rata sebagian besar responden angkatan 2012 teori tajwīd tersebut dikuasai, dengan jumlah prosentase $79 \%$. Untuk sifat huruf memperoleh hasil sebesar 36\% dengan kategori sebagian kecil menguasai hukum tersebut, untuk hukum nūn mati dan tanwīn, sebesar 82\% sebagian besar hukum tersebut dikuasai, untuk hukum igām șagir 69\% dengan kategori sebagian besar menguasai tersebut dikuasai, untuk hukum gunnaћ sebesar $88 \%$ dengan kategori sebagian besar hukum tersebut dikuasai, untuk hukum mad tobi'i seebsar $93 \%$ dengan kategori hampir seluruhnya hukum tersebut dikuasai, untuk mad far'i sebesar $67 \%$ sebagian besar hukum tersebut dikuasai, untuk hukum mim mati sebesar $81 \%$ dengan kategori sebagian besar kategori tersebut dikuasai, untuk hukum Qalqala $\hbar$ sebesar 89\% dengan kategori sebagian besar hukum tersebut dikuasai, untuk hukum alif lām sebanyak 92\% dengan kategori hampir seluruhnya hukum tersebut dikuasai, untuk hukum Tafkhìm dan $\operatorname{tarq} \bar{\imath} q$, sebanyak $83 \%$ dengan kategori sebagian besar hukum tersebut dikuasai, untuk hukum bacaan musykīlat dengan persentase sebesar 71\% dengan kategori sebagian besar hukum tersebut dikuasai, dan yang terakhir untuk hukum tanda waqaf sebesar $35 \%$ dengan kategori sebagian kecil hukum tersebut dikuasai.

Selanjutnya, pada rahan pemahaman atau penguasaan teori tajwīd, rata-rata sebagian besar responden angkatan 2013 menguasai teori tajwīd tersebut, dengan jumlah prosentase 74\%. Untuk sifat huruf, sebanyak 41\% dengan kategori hampir setengahnya hukum tersebut dikuasai. Untuk hukum nūn mati dan tanwīn, sebesar 74\% dengan kategori sebagian besar hukum tersebut dikuasai, untuk hukum idgham șagīr, sebanyak 63\% dengan kategori sebagian besar hukum tersebut dikuasai. Untuk hukum gunnaћ, sebesar $88 \%$ dengan kategori sebagian besar hukum tersebut dikuasai. Untuk hukum mad tobi'i, sebesar 94\% dengan kategori hampir seluruhnya hukum tersebut dikuasai. Untuk hukum mad far' $i$, sebesar 68\% dengan kategori sebagian besar hukum tersebut dikuasai. Untuk hukum mìm mati, sebesar $76 \%$ dengan kategori sebagian besar hukum tersebut dikuasai. Untuk hukum qolqola $\hbar$, sebesar $87 \%$ dengan kategori sebagian besar hukum tersebut dikuasai. Untuk hukum alif lām, sebesar $91 \%$ dengan kategori 
hampir seluruhnya hukum tersebut dikuasai. Hukum Tafkhìm dan tarqīq, sebanyak $82 \%$ dengan kategori sebagian besar dikuasai. Untuk hukum bacaan musykīlat, sebanyak 73\% dengan kategori sebagian besar hukum tersebut dikuasai. Dan terakhir, untuk tanda waqaf sebanyak $80 \%$ dengan kategori sebagian besar tanda waqaf dikuasai oleh responden angkatan 2013.

Terakhir, untuk angkatan 2014, dengan jumlah responden sebanyak 56 responden, pada ranah pemahaman atau penguasaan teori tajwīd, rata-rata sebagian besar responden angkatan 2014 menguasai teori tajwīd tersebut, dengan jumlah prosentase $83 \%$. Untuk sifat huruf, sebanyak 34\% dengan kategori sebagian kecil hukum tersebut dikuasai. Untuk hukum nūn mati dan tanwin, sebesar 71\% dengan kategori sebagian besar hukum tersebut dikuasai, untuk hukum Idgām sagir, sebanyak 57\% dengan kategori sebagian besar hukum tersebut dikuasai. Untuk hukum gunnah, sebesar $85 \%$ dengan kategori sebagian besar hukum tersebut dikuasai.-Untuk hukum mad tobi' $i$, sebesar $88 \%$ dengan kategori sebagian besar hukum tersebut dikuasai. Untuk hukum mad far' $i$, sebesar $63 \%$ dengan kategori sebagian besar hukum tersebut dikuasai. Untuk hukum mìm mati, sebesar $73 \%$ dengan kategori sebagian besar hukum tersebut dikuasai. Untuk hukum Qalqalaћ, sebesar 85\% dengan kategori sebagian besar hukum tersebut dikuasai. Untuk hukum alif lām, sebesar $87 \%$ dengan kategori sebagian besar hukum tersebut dikuasai. Hukum Tafkhìm dan tarqīq, sebanyak 79\% dengan kategori sebagian besar dikuasai. Untuk hukum bacaan musykīlat, sebanyak 41\% dengan kategori hampir setengahnya hukum tersebut dikuasai. Dan terakhir, untuk tanda waqaf sebanyak 52\% dengan kategori lebih dari setengahnya tanda waqaf dikuasai oleh responden angkatan 2014.

\section{Penguasaan praktek tajwīd}

Dalam penguasaan praktek tajwīd ini, untuk angkatan 2012 rata rata mendapatkan hasil $82 \%$ yang masuk kedalam kategori baik. Jika dilihat Selanjutnya untuk angkatan 2013 rata-rata yang diperoleh sebesar $83,2 \%$ yang masuk pula kedalam kategori baik. Terakhir untuk angkatan 2014, rata-rata yang diperoleh sebesar 73,25\% dengan kategori baik. Praktek tajwīd di dalam instrument tersebut memakai tes bacaan Al-Qur’ān.

Jika dilihat dari data yang telah diteliti lalu dianalisis, maka kita bisa simpulkan bahwa tingkat penguasaan praktek tajwīd yang diimplementasikan dalam bentuk baca Al-Qur'ān, mayoritas responden angkatan 2012 sampai 2014 berada pada tingkat TT. Itu artinya mereka baik di dalam membaca Al-Qur’ān. Akan tetapi belum mencapai tingkat Tahsīn atau Tilawah, atau tingkat layak untuk menjadi seoraang yang professional dan berkualitas di dalam membaca dan mengamalkannya. Menurut Hanapi (2013, hlm.5) tujuan utama mempelajari ilmu Tahsīn Tilawaћ adalah menjaga lisan dari kesalahankesalahan ketika membaca Al-Qur'ān Dalam rangka memenuhi perintah Allāh Swt yang ditegaskan oleh Rasul Allāh melalui sunnah-sunnahnya. Senada dengan itu pun, Menurut Annuri (2009, hlm. 3) urgensi dari Tilawaћ Al-Qur'ān adalah sebagai berikut : (a) Tilawah yang baik dan benar, sebagaimana ayat Al-Qur'ān itu diturunkan, sangat dicintai oleh Allāh. AlQur'ān diwahyukan Allāh melalui malaikat jibril kepada Rasul Allāh dengan bacaan yang tartil, begitu juga Rasul Allāh membaca dan mengajarkan kepada sahabatnya dengan bacaan yang tartil, para sahabat Rasul Allāh membaca dan mengajarkan Al-Qur'ān kepada tabi'in juga dengan bacaan yang tartil dan begitu seterusnya. (b) Tilawah yang bagus akan memudahkan pembacanya atau orang yang mendengarkan menghayati Al-Qur'ān. Menghayati Al-Qur'ān merupakan misi turunnya Al-Qur'ān. Allāh Swt Berfirman "Kitab yang Kami turunkan kepadamu 
penuh dengan berkah supaya mereka memperhatikan ayat-ayat-Nya dan supaya mendapat pelajaran orang-orang yang mempunyai fikiran".

Hampir tidak mungkin pembaca AlQur'ān yang tidak bagus bacaannya dapat menghayati Al-Qur'ān dengan baik, begitu juga orang yang mendengarkan bacaannya, apalagi jika bacaan itu dilakukan Dalam shalat. (c) Tilawah yang bagus akan memudahkan seseorang meraih pahala dari Allāh dengan sangat baik. (d) Tilawaћ yang bagus memungkinkan seseorang mengajarkan Al-Qur'ān kepada orang lain, minimal kepada keluarganya. (e) Tilawaћ yang bagus dapat mengangkat kualitas seseorang. Seperti sabda Rasul Allāh :"orang yang ahli Dalam Al-Qur'ān akan bersama dengan para malaikat pencatat yang mulia lagi taat. Dan orang yang terbata-bata membaca Al-Qur'ān dan dia bersusah payah mempelajarinya, baginya pahala dua kali lipat" (H.R Bukhāri, Muslim dan Abū Dāwud).

\section{Perbandingan penguasaan teori dan praktek tajwīd tiap angkatan}

Dari hasil perhitungan yang diperoleh peneliti dengan di bantu aplikasi IBM SPSS, secara umum bisa disimpulkan dalam penguasaan teori tajwīd ini, setiap angkatan memiliki rata-rata perbedaan. Akan tetapi jika dilihat dari signifikansi perbedaan yang jelas, bahwa perbedaan signifikansi antara angkatan 2012 dan 2013 sebesar 0,018. itu tandanya signifikansi perbedaan tersebut $<0,05$ dan itu artinya antara 2012 dengan 2013 terdapat perbedaan. Selanjutnya untuk angkatan 2012 dan 2014, adanya Signifikansi perbedaan sebesar 0,00 itu tandanya siginifikansi perbedaan tersebut $<0,05$. Sedangkan untuk angkatan 2013 dan 2014 tidak adanya signifikansi perbedaan dikarenakan signifikansi tersebut $>0,05$ yaitu sebesar 0,53 .

Selanjutnya, dapat diketahui bahwa nilai signifikansi dari perbandingan angkatan dalam kategori praktek tajwīd adalah 0,89. Itu artinya signifikansi berada $>0,05$. Maka bisa dilihat jika signifikansi lebih besar dari 0,05 maka bisa disimpulkan bahwa secara umum, setiap angkatan dalam kategori praktek tajwīd tidak memiliki perbedaan.

\section{Latar belakang pendidikan mempengaruhi penguasaan teori dan praktek tajwìd}

Menurut Ismail (1995: 17) Ilmu tajwīd merupakan bagian dari ulumul Qur'an yang perlu dipelajari, mengingat ilmu ini berkaitan dengan bagaimana seseorang dapat membaca Al-Qur'ān dengan baik. Sebagai Ilmu, tajwīd dapat berdiri sendiri karena mempunyai syarat-syarat ilmiah, seperti adanya tujuan, fungsi dan objek serta sistematika tersendiri. Senada dengan itu, Ilmu Tajwīd adalah ilmu yang berguna untuk mengetahui bagaimana cara melafalkan huruf yang benar dan dibenarkan, baik cara melafalkan huruf yang benar dan dibenarkan, baik berkaitan dengan sifat, mad dan sebagainya, misalnya Tarqīq, Tafkhim dan selain keduanya.

Setelah dilakukan uji hipotesis, maka dengan pengambilan keputusan berdasarkan probabilitas jika probabilitas Ho >0,05 maka Ho diterima, sedangkan apabila $<0,05$ maka Ha diterima dan Ho ditolak. Pada hasil yang diperoleh Sig. berada $>0,05$ Artinya tidak adanya pengaruh latar belakang pendidikan terhadap penguasaan teori tajwīd. Setelah data telah diuji prasyarat analisis selanjutnya dilakukan analisis untuk menjawab hipotesis, dilakukan uji hasil uji koefisien kolerasi, diperoleh nilai korelasi sebesar $-0,142$ berada pada rentang dibawah 0,00-0,199 itu artinya hubungan antara latar belakang pendidikan dengan penguasaan teori tajwīd benar-benar sangat rendah. Adapun besar signifkansinya yaitu $>0,05$ artinya tidak ada hubungan yang signifikan antara latar belakang pendidikan dengan penguasaan teori tajwīd mahasiwa angkatan 2012-2014 tersebut. Adapun untuk mengetahui hasil 
Regresi Linier sederhana, maka diperoleh output variabel independent (X) tidak berpengaruh terhadap respon Y. pada tabel di atas, Ho diterima (signifikansi $>0,05$ ) yang menandakan bahwa variabel $\mathrm{X}$ tidak berpengaruh terhadap $\mathrm{Y}$, dan hal ini menandakan persamaan regresinyaadalah tidak signifikan. Dan yang terakhir untuk uji koefisien determinasi, Diperoleh 4\% memiliki makna terdapat pengaruh variabel independen (latar belakang) terhadap dependen (penguasaan) dan selebihnya yaitu $96 \%(100 \%$ - 20\%) dapat dipengaruhi oleh faktor lain yang tidak diuraikan dalam penelitian ini.

Selanjutnya untuk uji hipotesis praktek tajwīd, hasil yang diperoleh pula Sig. berada $>0,05$ Artinya sama halnya tidak adanya pengaruh latar belakang pendidikan terhadap penguasaan praktek tajwīd. Untuk hasil uji koefisien kolerasi, diperoleh nilai korelasi sebesar $-0,146$ berada pada rentang dibawah 0,00-0,199 itu artinya hubungan antara leatar belakang pendidikan dengan penguasaan teori tajwīd benar-benar sangat rendah. Adapun besar signifkansinya yaitu $>0,05$ artinya tidak ada hubungan yang signifikan antara latar belakang pendidikan dengan penguasaan teori tajwīd mahasiwa angkatan 2012-2014 tersebut. Adapun untuk mengetahui hasil Regresi Linier sederhana, maka diperoleh output variabel independent (X) tidak berpengaruh terhadap respon Y. pada tabel di atas, Ho diterima (signifikansi $>0,05$ ) yang menandakan bahwa variabel $\mathrm{X}$ tidak berpengaruh terhadap $\mathrm{Y}$, dan hal ini menandakan persamaan regresinyaadalah tidak signifikan. Dan yang terakhir untuk uji koefisien determinasi, diperoleh $4,4 \%$ memiliki makna terdapat pengaruh variabel independen (latar belakang) terhadap dependen (penguasaan) dan selebihnya yaitu $95,6 \%(100 \%-20 \%)$ dapat dipengaruhi oleh faktor lain yang tidak diuraikan dalam penelitian ini. Bisa jadi latar belakang lain yang mempengaruhi seperti tingkat kemauan atau motivasi yang tinggi yang dimiliki oleh masing-masing responden. Untuk itu perlu adanya tindak lanjut dari PRODI IPAI itu sendiri, seperti adanya treatment atau mengadakan mata kuliah baru yang khusus mengkaji ilmu tajwīd untuk meningkatkan kualitas PRODI itu sendiri demi mencetak calon guru yang profesional.

\section{REFERENSI}

Fakhruddin, A. (2014). Urgensi Pendidikan Nilai Untuk Memecahkan Problematika Nilai Dalam Konyeks Persekolahan. Ta'lim , 96.

Isjoni. (2009). Guru Sebagai Motivator

Perubahan. Yogyakarta: Pustaka Pelajar.

Ismail, A. M., \& Nawawi, M. U. (1995). Pedoman Ilmu Tajwìd. Surabaya: Karya Abditama.

Ruhimat, T. (2009). Kurikulum Pembelajaran. (M. Sumantri, Ed.) Bandung: Tim Pengembang MKDP Kurikulum Pembelajaran.

Saudagar, F. (2009). Pengembangan Profesionalitas Guru. (H. M. Yamin, Ed.) Jambi: Gaung Persada (GP Press) Jakarta.

Sugiyono. (2011). Metode Penelitian

Pendidikan. Bandung: Cv.Alfabeta. 